\title{
Substitution of Non-Protein Nitrogen for True Protein Increases Microbial Growth and Degradation of Fibrous Carbohydrates from Buffel Grass
}

\author{
José Adelson Santana Neto ${ }^{1}$, Juliana Silva de Oliveira ${ }^{2}$, Edson Mauro Santos ${ }^{2}$, Elizabete Cristina Batista da Costa ${ }^{2}$,

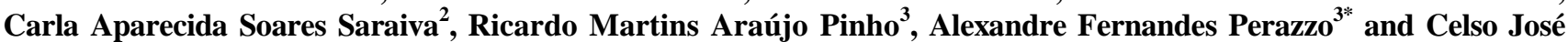 \\ Bruno de Oliveira ${ }^{2,4}$ \\ ${ }^{1}$ Universidade Federal de Sergipe, Av. Marechal Rondon, s/n, Jd. Rosa Elze. São Cristóvão - SE, Brazil \\ ${ }^{2}$ Universidade Federal da Paraíba, Centro de Ciências Agrárias, Campus II, Rodovia BR 079, Km 12, Areia - PB, Brazil \\ ${ }^{3}$ Universidade Federal do Maranhão, BR-222, KM 04, S/N, Boa Vista, Chapadinha, MA - Brazil \\ ${ }^{4}$ Global One Health initiative (GOHi), Ohio State University (OSU), Columbus, Ohio, USA \\ For correspondence: alexandreperazzo@hotmail.com \\ Received 17 June 2020; Accepted 26 September 2020; Published 10 January 2021
}

\begin{abstract}
The aim of this study was to evaluate the effects of different sources of nitrogenous compounds on the in vitro utilisation of neutral detergent fibre from buffel grass in advanced phenological stage, the experiment consisted of testing five levels of substitution of urea for casein: $0,25,50,75$ and 100\%. The effects of the substitution levels were evaluated by in vitro incubation at different times: $0,3,6,9,12,24,36,48,72$ and $96 \mathrm{~h}$. The degradation rate of potentially degradable NDF increased up to the replacement level of $50 \%$, but declined by 6.53 and $13.57 \%$ in the treatments with 75 and $100 \%$ substitution of urea for casein, respectively, as compared with the treatment without substitution. Discrete lag time was reduced by $1.31 \mathrm{~h}$ in the treatment with $50 \%$ substitution and by $2.7 \mathrm{~h}$ at $100 \%$ substitution, as compared with $0 \%$ substitution. The substitution of up to $50 \%$ non-protein nitrogen for true protein increased microbial growth efficiency by $16.1 \%$ as compared with the treatment without substitution. Acetate and propionate concentrations were not affected by the substitution of urea for casein. The use of 50\% non-protein nitrogen and 50\% true protein as nitrogen sources for rumen microorganisms favour microbial growth and optimise the degradation of neutral detergent fibre from low-protein buffel grass. (C) 2021 Friends Science Publishers
\end{abstract}

Keywords: Ammonia; Casein; Rumen; Urea

\section{Introduction}

Tropical grasses produce large amounts of dry matter all year long. However, at certain times of the year, such as in the drought period, the fibre and protein contents of those forages typically increase and decrease, respectively, resulting in lower digestibility and nutritional quality (Arruda et al. 2010).

Buffel grass (Cenchrus ciliares) is a species adapted to the soil-climatic conditions of arid regions of the world, where it has the potential to be used in livestock systems by virtue of its great drought resistance. Notwithstanding this fact, the rapid phenological development of this species in the drought period leads to a reduction in its protein value, with crude protein (CP) contents reaching around 3\% (Santos et al. 2005). On the other hand, neutral detergent fibre (NDF) contents increase under those circumstances, easily surpassing $70 \%$ on a dry matter basis.

The use of non-protein nitrogen (NPN) at levels exceeding $27 \%$ of the total $\mathrm{CP}$ of the diet has shown to support satisfactory production performance in ruminants (Mallmann et al. 2006). For cellular multiplication to occur, the microbial flora requires peptides, amino acids, and ammonia, which are hydrolysed from a source of true protein or NPN (Kanjanapruthipong and Leng 1998). Therefore, studies addressing the effects of different sources of nitrogenous compounds on microbial growth and putative changes in the digestion of the fibrous carbohydrates could provide valuable information to improve the utilisation of the fibrous fractions of buffel grass during the drought period of the year.

In this study, we investigated the effects of different sources of nitrogenous compounds on the in vitro utilisation of neutral detergent fibre.

To cite this paper: Neto JAS, JSD Oliveira, EM Santos, ECBD Costa, CAS Saraiva, RMA Pinho, AF Perazzo, CJBD Oliveira (2021). Substitution of nonprotein nitrogen for true protein increases microbial growth and degradation of fibrous carbohydrates from buffel grass. Intl J Agric Biol 25:492-500 


\section{Materials and Methods}

The experiment was carried out at the Laboratory of Forage Crops of the Department of Animal Science, Centre for Agrarian Sciences, Federal University of Paraíba (UFPB), located in Areia - PB, Brazil. A rumen-fistulated goat was used as a donor of rumen fluid. The goat was fed elephant grass only for seven consecutive days prior to rumen-fluid collection in order to reduce the concentration of nitrogenous compounds in the rumen fluid.

The experimental procedures were previously approved by the Ethics Committee on the Use of Animals (CEUA) of the Centre for Biotechnology (CBiotec) at UFPB (approval no. 0209/14), which are in accordance with the resolutions of the National Council for Control of Animal Experimentation (CONSEA).

Buffel grass (Cenchrus Ciliares) in advanced phenological stage was collected from a deferred pasture. The grass was dried in a forced-air oven $\left(60^{\circ} \mathrm{C}\right)$ and ground in a knife mill with 2-mm sieves for the incubation procedures and in a knife mill with 1-mm sieves for dry matter determinations (DM; method 930.15), crude protein (CP; method 968.06), ether extract (EE; 954.05), and mineral matter (MM; method 942.05) as proposed by AOAC (2012). Neutral detergent fibre (NDF), acid detergent fibre (ADF), and lignin contents were determined (Soest 1967) and corrected for ash and nitrogenous compounds. Neutral detergent insoluble nitrogen was expressed as a proportion of total nitrogen (NDIN/TN), as previously described (Licitra et al. 1996). Total carbohydrates (TC) were estimated by the following equation: $\mathrm{TC}(\%)=100-(\% \mathrm{CP}+\% \mathrm{EE}+\% \mathrm{MM})$. Nonfibrous carbohydrates (NFC) were calculated as NFC $=100$ $-(\% \mathrm{CP}+\% \mathrm{NDFap}+\% \mathrm{MM}+\% \mathrm{EE})$, where NDFap is NDF free of ash and protein, as described by Sniffen et al. (1992) (Table 1).

The inoculum containing active microbial populations was obtained from rumen fluid sampled three hs after first feeding. The fluid was saturated with carbon dioxide $\left(\mathrm{CO}_{2}\right)$ and incubated at $39^{\circ} \mathrm{C}$. The intermediate phase was collected, centrifuged at $500 \mathrm{rpm}$ for $10 \mathrm{~min}$, and supernatant was discarded in order to obtain the inoculum containing active microbial population (Russell and Martin 1984). The pellet was resuspended another two times in autoclaved McDougall buffer $\left(9.80 \mathrm{~g} \mathrm{NaHCO}_{3} ; 4.65 \mathrm{~g}\right.$ $\mathrm{Na}_{2} \mathrm{HPO}_{4} * 2 \mathrm{H}_{2} \mathrm{O} ; 0.57 \mathrm{~g} \mathrm{KCl} ; 0.12 \mathrm{~g} \mathrm{MgSO}_{4} * 7 \mathrm{H}_{2} \mathrm{O}$; and $0.04 \mathrm{~g} \mathrm{CaCl}_{2}$, diluted with distilled water up to the volume of $1000 \mathrm{~mL}$ ).

The experiment consisted of testing five levels of substitution of non-protein nitrogen (NPN) (urea) for true protein (casein). Urea $(9.58 \mathrm{mg}$ ) was added so that ammonia nitrogen concentration in the rumen fluid was $17.76 \mathrm{mg} \mathrm{dL}^{-}$ ${ }^{1}$, corresponding to the treatment with $100 \%$ NPN. The urea was used as a source of NPN, and casein AR (Dinâmica Química Contemporânea Ltd., Brazil) was used as a source of true protein. After the ammonia nitrogen concentration was defined, the experimental levels were obtained through fractional replacements of urea (NPN) by casein.

The experiment was set up as a completely randomised design with five treatments and three replicates. The treatments contained the following proportions of nitrogen sources: $100 \%$ urea-derived nitrogen $(9.59 \mathrm{mg})$ and $0 \%$ casein $(0 \mathrm{mg}) ; 75 \%$ urea $(7.20 \mathrm{mg})$ and $25 \%$ casein $(2.39 \mathrm{mg}) ; 50 \%$ urea $(4.80 \mathrm{mg})$ and $50 \%$ casein $(4.80 \mathrm{mg})$; $25 \%$ urea $(2.39 \mathrm{mg})$ and $75 \%$ casein $(7.20 \mathrm{mg})$; and $0 \%$ urea $(0 \mathrm{mg})$ and $100 \%$ casein $(9.59 \mathrm{mg})$. In addition to the nitrogen source, each replicate (incubation bottle) consisted of growth medium $(28 \mathrm{~mL}$ of McDougall buffer and $7 \mathrm{~mL}$ of inoculum) and $350 \mathrm{mg}$ buffel grass. Bottles containing growth medium only $(35 \mathrm{~mL})$ served as blank. In vitro digestibility and microbial growth parameters were determined in triplicate per treatment at each sampling time. The $35 \mathrm{~mL}$ of the nitrogen sources were used.

Three bottles without inoculum served as blank for digestibility determinations.

Each bottle was then saturated with $\mathrm{CO}_{2}$, capped, and sealed. Bottles were incubated in a BOD (Biochemical Oxygen Demand) incubator for $96 \mathrm{~h}$ at $39^{\circ} \mathrm{C}$. Samplings were performed at $0,3,6,9,12,24,48,72$ and $96 \mathrm{~h}$ of incubation. Produced gases were removed from all bottles in these 3-h intervals using syringes. At the end of each incubation time, the bottles were removed from the BOD incubator and the residue was filtered for NDF degradability determinations. A $2.0-\mathrm{mL}$ sample of growth medium was collected from each experimental unit, placed in microtubes and centrifuged at $5200 \mathrm{rpm}$ for $10 \mathrm{~min}$. Supernatant was then frozen for later analysis of the concentration of ammonia nitrogen $(\mathrm{N}-$ $\left.\mathrm{NH}_{3}\right)$. The pellet was resuspended in $\mathrm{NaCl}$ solution $(0.9 \%$ $\mathrm{w} / \mathrm{v})$ and centrifuged at $5200 \mathrm{rpm}$ for $10 \mathrm{~min}$; the supernatant was discarded; and the pellet was resuspended again in $\mathrm{NaCl}$ solution $(0.9 \% \mathrm{w} / \mathrm{v})$ and frozen for later determination of microbial protein. Ammonia concentration was determined by a colorimetric method (Chaney and Marbach 1962), whereas microbial protein content was obtained following the method of Bradford (1976).

For volatile fatty acids (VFA) analysis, a $2.0-\mathrm{mL}$ sample of growth medium was collected from all experimental units at $48 \mathrm{~h}$ of incubation, transferred to microtubes, and centrifuged at $5200 \mathrm{rpm}$ for $10 \mathrm{~min}$. The supernatant was then frozen for VFA profiling by means of high-performance liquid chromatograph (HPLC) (SHIMADZU, SPD-10A VP) coupled to an ultraviolet (UV) detector operating at a wavelength of $210 \mathrm{~nm}$. A C18 column (SHIMADZU) with $30 \mathrm{~cm} \times 7.9 \mathrm{~mm}$ diameter and $0.6 \mathrm{~mL} \mathrm{~min}{ }^{-1}$ flow was used under a pressure of $69 \mathrm{kgf}$, with the water mobile phase in $1 \%$ orthophosphoric acid and injected volume of $20 \mu \mathrm{L}$. Acetate, propionate, and butyrate concentrations; acetate/propionate ratio; total VFA and lactate concentrations were determined.

Blanks (bottles containing the incubation solutions without substrate) were also incubated to adjust the existing 
variations. The bottles were closed using rubber corks and their contents were homogenized by agitation. In order to determine the NDF degradability at each sampling period, the residual material from each bottle was collected and washed with warm water in a filtering crucible until growth medium was removed. This residue was dried in an air oven and, weighed on an analytical scale after 24 h. The NDF content, considering the indigestible part of the feed, was determined from this residue by the method of Soest (1967).

The NDF residues at the different times, for each treatment, were analysed by the Gauss-Newton algorithm and adjusted to the non-linear logistic model described by Milgen et al. (1991) and Detmann et al. (2011).

$$
R t=\mathrm{U} \times \frac{[\mathrm{c} \times \exp (-\mathrm{p} \times \mathrm{t})-\mathrm{p} \times \exp (-\mathrm{c} \times \mathrm{t})]}{(\mathrm{c}-\mathrm{p})}+I \text { (I) }
$$

Where, Rt = undegraded NDF residue at time " $\mathrm{t}$ " (\%); $\mathrm{U}=$ potentially degradable fraction of $\mathrm{NDF}(\mathrm{pdNDF})(\%) ; \mathrm{I}=$ undegradable fraction of NDF (iNDF) $(\%) ; \mathrm{c}=$ fractional rate of degradation of $\operatorname{pdNDF}\left(\mathrm{h}^{-1}\right) ; \mathrm{p}=$ fractional rate of lag time $\left(\mathrm{h}^{-1}\right)$; and $\mathrm{t}=$ time $(\mathrm{h})$.

The function described in (I) is considered symmetrical in relation to the fractional degradation rates $\mathrm{c}$ and $\mathrm{p}$, the lowest values of which are frequently known to be associated with c (Vieira et al. 1997). However, when the fractional rates $\mathrm{c}$ and $\mathrm{p}$ tend towards the same estimate, mathematical indeterminacy will be observed, and the model should be re-parameterised according to L'Hôspital's rule (Milgen et al. 1991):

$$
R t=\mathrm{U} \times(1+\lambda \times \mathrm{t}) \operatorname{xexp}(-\lambda x t)+I \text { (II) }
$$

Where, $\lambda=$ combined fractional rate of lag time and degradation $\left(\mathrm{h}^{-1}\right)$. In this situation, because parameter $\lambda$ simultaneously describes the lag-time and degradation rates, the fractional rate of degradation was determined from $\lambda$, using the gamma-2 distribution properties (Ellis et al. 1994):

$$
c^{\prime}=0.59635 \times \lambda(\text { III) }
$$

Where, $c^{\prime}=$ fractional rate of degradation of $\operatorname{pdNDF}\left(\mathrm{h}^{-1}\right)$ for the cases in which the re-parameterised model is used (Equation II).

Discrete lag time was obtained following the models of Vieira et al. (1997):

$$
x=\frac{R(O)-R(t \overline{)})}{t e x} \text { (IV) }
$$

Where, $\mathrm{L}=$ discrete lag time $(\mathrm{h}) ; \mathrm{R}(0)=$ undegraded NDF residue at $\mathrm{t}=0(\%) ; \mathrm{R}(\mathrm{ti})=$ undegraded $\mathrm{NDF}$ residue obtained at the inflection point of the degradation $(\%) ; \mu=$ derivative of the degradation curve adjusted to the inflection point (maximum rate of degradation of the substrate) $\left(\mathrm{h}^{-1}\right)$; ti = time corresponding to the inflection point of the degradation curve $(\mathrm{h})$.

The ti values were calculated according to the observations of Milgen et al. (1991) (Equations I and II, respectively):

$$
\begin{gathered}
t i=\frac{\ln (c)-\ln (p)}{(\mathrm{c}-\mathrm{p})}(\mathrm{V}) \\
t i=\frac{1}{\lambda}(\mathrm{VI})
\end{gathered}
$$

The specific microbial growth rate in relation to pdNDF was calculated in accordance with the hypothesis proposed by Beuvink and Kogut (1993):

$$
\text { Sgr }=\frac{\mu}{\mathrm{U}}(\mathrm{VII})
$$

Where, $\operatorname{Sgr}=$ specific microbial growth rate $\left(h^{-1}\right)$. After the Sgr estimates were calculated, the microbial growth efficiencies in relation to pdNDF were estimated by following the theories of Pirt (1965):

$$
\frac{1}{Y}=\frac{m}{\mathrm{Sgr}}+\frac{1}{Y m}(\mathrm{VIII})
$$

Where, $\mathrm{Y}=$ microbial efficiency $(\mathrm{g}$ cells $\mathrm{g}$ degraded carbohydrates $\left.^{-1}\right) ; \mathrm{m}=$ requirement for the maintenance of microorganisms ( $\mathrm{g}$ carbohydrates $\mathrm{g}$ cells $\mathrm{s}^{-1} \mathrm{~h}^{-1}$ ); and $\mathrm{Ym}=$ theoretical maximum efficiency of the microorganisms on the substrate ( $\mathrm{g}$ cells $\mathrm{g}$ degraded carbohydrates ${ }^{-1}$ ). The Ym parameter was adopted as reference, with the value of $0.4 \mathrm{~g}$ cells $\mathrm{g}^{-1}$ degraded carbohydrates, while $\mathrm{m}$ was set as $0.05 \mathrm{~g}$ carbohydrates $\mathrm{g}$ cells $^{-1} \mathrm{~h}^{-1}$, as recommended by Russell et al. (1992).

The effectively degraded fractions of NDF were calculated as proposed by Costa et al. (2008), in an adjusted version of the methodology described by Ørskov and McDonald (1979):

$$
E D F=\lim t \rightarrow \infty \int_{0}^{t}\left[\left(f(t) \times\left(-\frac{d R t}{d t}\right)\right] d t(\mathrm{IX})\right.
$$

Where, EDF: effectively degraded fraction of NDF $(\%) ; f(\mathrm{t})$ $=$ function relative to the displacement flow of solids in the rumen environment. To define the function described in (IX), we assumed ruminal displacement flow of solids with gamma-1 distribution (Ellis et al. 1994 ), to which the hypothetical values of $0.020,0.035$, and 0.050 were allocated.

In this way, in the context of the equations (X), EDF was calculated as follows:

$$
E D F=\mathrm{U} \times \frac{\lambda^{2}}{(\lambda+\mathrm{k})^{2}}(\mathrm{X})
$$

The models were fitted to the degradation profiles as a function of the different substitution levels and were compared descriptively. The $\mathrm{N}_{-} \mathrm{NH}_{3}$ and microbial protein concentrations obtained at the incubation times of 0 and $48 \mathrm{~h}$ were evaluated by variance and regression analyses. The criteria used in the choice of the model were the significance of regression coefficients at $5 \%$ probability by Tukey's test and the determination coefficient $\left(r^{2}\right)$, which was obtained as the sum of regression 
squares divided by the sum of squares of treatments and biological phenomenon.

Volatile fatty acid and lactate data were subjected to variance and regression analyses. The criteria for the choice of the regression models were the significance of the regression parameters, determination-coefficient values, and the biological interpretation of the regression curves. The variables were analysed statistically by Tukey's test at the $5 \%$ significance level.

The asymptotic standard deviation (ASD) was calculated from the root mean residual square of each model. All statistical analyses, both linear and non-linear, were performed using SAS software (Statistical Analysis System).

\section{Results}

The mean rumen ammonia values varied between 1.69 and $7.58 \mathrm{mg} \mathrm{dL}^{-1}$ at $0 \mathrm{~h}$ and between 19.91 and $26.0 \mathrm{mg} \mathrm{dL}^{-1}$ at $48 \mathrm{~h}$ (Table 2). All treatments provided sufficient uptake of ammonia for the cellulose- and hemicellulose-degrading microorganisms. After $48 \mathrm{~h}$ of incubation, ammonia values decreased linearly $(P<.05)$ from 26.0 to $19.25 \mathrm{mg} \mathrm{dL}^{-1}$ as per the substitution for true protein increased from 0 to $100 \%$ (Fig. 1a).

At the beginning of incubation $(0 \mathrm{~h})$, microbial protein did not differ across the treatments $(P>.05)$ averaging $161.9 \mathrm{mg} \mathrm{L}^{-1}$. However, at $48 \mathrm{~h}$ of incubation, the treatments fitted a quadratic model $(P<.05)$, with maximum microbial protein attained at $46.88 \%$ of substitution of NPN for true protein, according to the derivation of the second-degree equation (Table 2, Fig. 1b).

No significant effects of substitution or incubation time were observed $(P>.05)$ on the $\mathrm{pH}$ of the medium (Table 3), which averaged 7.15 and 7.26 at 0 and $48 \mathrm{~h}$ of incubation, respectively.

Rumen concentrations of acetate, propionate, and lactate and acetate/propionate ratio did not differ $(P>.05)$ according to the levels of replacement of urea by casein (Table 4). The respective variables averaged 51.5, 21.4, 0.45 , and $2.46 \mathrm{~m} M$.

Butyrate levels increased linearly $(P<.05)$, from 0.87 to $2.05 \mathrm{mM}$, as urea was replaced with casein $(0$ and $100 \%$ substitution, respectively).

The highest concentration of total VFA $(80.57 \mathrm{mM})$ was observed at $50 \%$ replacement of NPN. Supplementation with $50 \%$ TP increased the degradation of the fibrous fraction (pdNDF) (Table 5), which consequently led to higher concentrations of total VFA.

The replacement of non-protein nitrogen (urea) with a source of true protein (casein) increased the degradation rate of pdNDF up to the substitution level of $50 \%$. The treatment with $50 \%$ substitution showed a higher fractional rate of degradation resulting from the transformation of parameter $\lambda$, revealing a $17.42 \%$ increase compared with the treatment with $0 \%$ substitution. The degradation rate of pdNDF was declined by 6.53 and
Table 1: Chemical composition of buffel grass, urea, and casein

\begin{tabular}{|c|c|c|c|}
\hline Item & Forage & Urea & Casein \\
\hline Dry matter $\left(\mathrm{g} \mathrm{kg}^{-1}\right)$ & 854.4 & 982.1 & 900.0 \\
\hline Organic matter $\left(\mathrm{g} \mathrm{kg} \mathrm{DM}^{-1}\right)$ & 905.2 & 997.6 & 972.4 \\
\hline $\operatorname{Ash}\left(\mathrm{g} \mathrm{kg} \mathrm{DM}^{-1}\right)$ & 94.8 & 2.4 & 27.6 \\
\hline Crude protein $\left(\mathrm{g} \mathrm{kg} \mathrm{DM}^{-1}\right)$ & 49.8 & 2610.0 & 889.7 \\
\hline Ether extract $\left(\mathrm{g} \mathrm{kg} \mathrm{DM}^{-1}\right)$ & 16.6 & - & 3.2 \\
\hline Total carbohydrates $\left(\mathrm{g} \mathrm{kg} \mathrm{DM}^{-1}\right)$ & 838.8 & - & - \\
\hline${ }^{1} \mathrm{NDF}\left(\mathrm{g} \mathrm{kg} \mathrm{DM}^{-1}\right)$ & 857.0 & - & - \\
\hline${ }^{2} \mathrm{NDFap}\left(\mathrm{g} \mathrm{kg} \mathrm{DM}^{-1}\right)$ & 799.7 & - & - \\
\hline${ }^{3} \mathrm{ADF}\left(\mathrm{g} \mathrm{kg} \mathrm{DM}^{-1}\right)$ & 348.1 & - & - \\
\hline${ }^{4} \mathrm{NFC}\left(\mathrm{g} \mathrm{kg} \mathrm{DM}^{-1}\right)$ & 39.1 & - & - \\
\hline${ }^{5} \mathrm{TN}\left(\mathrm{g} \mathrm{kg} \mathrm{DM}^{-1}\right)$ & 8.0 & - & - \\
\hline${ }^{6} \mathrm{NDIN}\left(\mathrm{g} \mathrm{kg} \mathrm{DM}^{-1}\right)$ & 195.6 & - & - \\
\hline $\operatorname{Lignin}\left(\mathrm{g} \mathrm{kg} \mathrm{DM}^{-1}\right)$ & 76.6 & - & - \\
\hline
\end{tabular}

Table 2: Substitution of non-protein nitrogen (NPN) for true protein (TP) on the concentrations of ammonia nitrogen and microbial protein at 0 and $48 \mathrm{~h}$ of in vitro incubation

\begin{tabular}{|c|c|c|c|c|c|c|c|c|c|}
\hline \multicolumn{6}{|c|}{ Parameter Substitution of NPN for TP (\%) } & \multirow[t]{2}{*}{$\mathrm{CV}(\%)^{1}$} & \multicolumn{3}{|c|}{$\mathrm{R}^{2} P$-value } \\
\hline & 0 & 25 & 50 & 75 & 100 & & & & $\mathrm{Q}$ \\
\hline \multicolumn{10}{|c|}{$\mathrm{N}^{-\mathrm{NH}_{3}}\left(\mathrm{mg} \mathrm{dL}^{-1}\right)$} \\
\hline $0 \mathrm{~h}^{2}$ & 7.58 & 7.15 & 6.17 & 5.63 & 1.69 & 13.55 & 0.80 & 0.01 & Ns \\
\hline $48 \mathrm{~h}^{3}$ & 26.0 & 24.80 & 22.64 & 19.91 & 19.25 & 17.34 & 0.97 & 0.02 & $2 \mathrm{Ns}$ \\
\hline \multicolumn{10}{|c|}{ Microbial protein $\left(\mathrm{mg} \mathrm{L}^{-1}\right)$} \\
\hline $0 \mathrm{~h}^{4}$ & 161.33 & 162.00 & 162.05 & 163.03 & 161.33 & 31.51 & - & ns & Ns \\
\hline $48 h^{5}$ & 463.33 & 536.01 & 622.66 & 494.65 & 442.54 & 10.76 & 0.79 & ns & 0.02 \\
\hline
\end{tabular}

Table 3: Substitution of non-protein nitrogen (NPN) for true protein (TP) on the $\mathrm{pH}$ of the medium at 0 and $48 \mathrm{~h}$ of in vitro incubation

\begin{tabular}{|c|c|c|c|c|c|c|c|c|c|}
\hline \multirow[t]{2}{*}{ Parameter } & \multicolumn{5}{|c|}{ Substitution of NPN for TP } & \multirow[t]{2}{*}{$\mathrm{CV}(\%)^{1}$} & \multirow[t]{2}{*}{$\mathrm{R}^{2}$} & \multicolumn{2}{|c|}{$P$-value } \\
\hline & 0 & 25 & 50 & 75 & 100 & & & $\mathrm{~L}$ & $\mathrm{Q}$ \\
\hline & & & & $\mathrm{pH}$ & & & & & \\
\hline $0 \mathrm{~h}$ & 7.10 & 7.14 & 7.17 & 7.16 & 7.19 & 1.94 & - & ns & ns \\
\hline $48 \mathrm{~h}$ & 7.29 & 7.26 & 7.28 & 7.22 & 7.25 & 0.47 & - & ns & ns \\
\hline
\end{tabular}

$13.57 \%$ in the treatments in which 75 and $100 \%$, respectively of the NPN were replaced with TP (Table 5).

The treatment in which $50 \%$ of the NPN was substituted for TP provided a $1.31 \mathrm{~h}$ shorter estimate of discrete lag time than the treatment with $0 \%$ substitution and a $2.7 \mathrm{~h}$ shorter value compared with full substitution. Lag time declined by $1.31 \mathrm{~h}$ until the substitution level of $50 \%$.

Supplementation with the different nitrogenous compounds increased the specific growth rate of microorganisms only by $4.5 \%$ up to the substitution level of $50 \%$ (Table 6). However, this variable then decreased 10.9 to $24.9 \%$ from 75 to $100 \%$ substitution. The treatment in which $50 \%$ of NPN was replaced with TP provided the best results for microbial growth, which was $17.4 \%$ more efficient than in the treatment with $0 \%$ substitution. When, $100 \%$ of NPN was replaced with TP, the specific growth rate of microorganisms decreased by $13.7 \%$.

The efficiency of microbial growth on pdNDF ( $g$ 
Table 4: Concentrations of volatile fatty acids (VFA) and lactate according to the substitution of non-protein nitrogen (NPN) for true protein (TP)

\begin{tabular}{llllll}
\hline \multirow{2}{*}{ VFA $^{2}$} & \multicolumn{5}{c}{ Substitution of NPN for TP } \\
\cline { 2 - 6 } & $0 \%$ & $25 \%$ & $50 \%$ & $75 \%$ & $100 \%$ \\
\hline Acetate & 51.6 & 51.8 & 53.5 & 50.4 & 50.2 \\
Propionate & 20.8 & 21.30 & 24.9 & 20.0 & 20.0 \\
Butyrate & 0.87 & 0.94 & 1.56 & 1.61 & 2.05 \\
Lactate & 0.39 & 0.49 & 0.47 & 0.41 & 0.47 \\
A/P ${ }^{3}$ & 2.48 & 2.43 & 2.16 & 2.62 & 2.60 \\
Total VFA & 73.27 & 74.04 & 79.96 & 72.01 & 72.20 \\
Parameter & Regression equation & $\mathrm{CV}(\%)$ & $\mathrm{L}$ & $\mathrm{Q}$ & $\mathrm{R}^{2}$ \\
Acetate & $\hat{\mathrm{Y}}=51.5$ & 8.4 & 0.317 & 0.326 & - \\
Propionate & $\hat{\mathrm{Y}}=21.4$ & 14.8 & 0.491 & 0.152 & - \\
Butyrate & $\hat{\mathrm{Y}}=0.81+0.01 \mathrm{X}$ & 24.2 & 0.001 & 0.88 & 0.90 \\
Lactate & $\hat{\mathrm{Y}}=0.45$ & 23.6 & 0.707 & 0.500 & - \\
A/P & $\hat{\mathrm{Y}}=2.46$ & 20.6 & 0.634 & 0.488 & - \\
Total VFA & $\hat{\mathrm{Y}}=73.3+0.2 \mathrm{X}-0.002 \mathrm{X}^{2}$ & 1.1 & 0.001 & 0.001 & 0.58 \\
\hline${ }^{1}$ Levels of substitution of urea for casein; ${ }^{2}$ Concentration of VFA in millimolar $(\mathrm{m} M)$ \\
${ }^{3}$ Acetate/Propionate ratio & \multicolumn{4}{c}{}
\end{tabular}

Table 5: Estimates of rumen degradation parameters of potentially degradable neutral detergent fibre and asymptotic standard deviations (ASD) for the degradation profiles adjusted according to the substitution of non-protein nitrogen for true protein

\begin{tabular}{llllll}
\hline \multirow{2}{*}{ Parameter $^{1}$} & \multicolumn{5}{c}{ Substitution level } \\
\cline { 2 - 6 } & $0 \%$ & $25 \%$ & $50 \%$ & $75 \%$ & $100 \%$ \\
\hline $\mathrm{U}(\%)$ & 43.6 & 40.99 & 38.8 & 41.5 & 37.8 \\
$\lambda\left(\mathrm{h}^{-1}\right)$ & 0.1955 & 0.2134 & 0.2295 & 0.1826 & 0.1689 \\
$\mathrm{c}^{\prime}\left(\mathrm{h}^{-1}\right)^{2}$ & 0.1165 & 0.1272 & 0.1368 & 0.1089 & 0.1007 \\
RVDR $(\%)^{3}$ & 100 & 109.18 & 117.42 & 93.47 & 86.43 \\
L (h) & 8.79 & 8.05 & 7.48 & 9.41 & 10.18 \\
ASD & 9.60 & 9.01 & 8.61 & 9.25 & 9.87 \\
\hline
\end{tabular}
lag time and degradation; $c^{\prime}=$ fractional rate of degradation obtained from the conversion of parameter $\lambda ; \operatorname{RVDR}=$ relative value of the degradation rate; $\mathrm{L}=$ discrete lag time. ${ }^{2}$ Estimated according to gamma-2 distribution properties: c' $=$ $0.59635 \lambda .{ }^{3}$ Relative value of the degradation rate in relation to the forage $\left(0 \mathrm{mg} \mathrm{dL}^{-1}\right)$.

Table 6: Secondary parameters associated with microbial growth on the potentially degradable neutral detergent fibre according to the substitution of non-protein nitrogen for true protein.

\begin{tabular}{llllll}
\hline \multirow{2}{*}{ Parameter } & \multicolumn{5}{c}{ Substitution level } \\
\cline { 2 - 6 } & $0 \%$ & $25 \%$ & $50 \%$ & $75 \%$ & $100 \%$ \\
\hline$\mu^{1}$ & 3.13 & 3.22 & 3.27 & 2.79 & 2.35 \\
Sgr & 0.0719 & 0.0785 & 0.0844 & 0.0671 & 0.0621 \\
EMG & 312.95 & 348.78 & 363.37 & 308.15 & 302.55 \\
\hline $\begin{array}{l}1 \\
\mu\end{array}=$ maximum degradation rate $\left(\mathrm{h}^{-1}\right) ;$ Sgr $=$ specific microorganism growth rate $\left(\mathrm{h}^{-1}\right) ;$ \\
EMG = efficiency of microbial growth on pdNDF (g microbial DM kg degraded \\
carbohydrate $\left.{ }^{-1}\right)$
\end{tabular}

microbial DM kg degraded carbohydrate ${ }^{-1}$ ) behaved similarly to the other evaluated parameters. The substitution of up to $50 \%$ provided an approximately $16.1 \%$ more efficient microbial growth $(363.37 \mathrm{~g}$ microbial DM $\mathrm{kg}$ degraded carbohydrate ${ }^{-1}$ ). Full substitution of NPN for TP, in turn, led to a $3.3 \%$ reduction in this variable in comparison with the treatment without substitution.

The highest estimates for effective degradation of pdNDF were observed in the treatment with $0 \%$ substitution, in which the effectively degraded fraction of pdNDF would increase by $20.7 \%$ at the passage rate of $0.035 \mathrm{~h}^{-1}$ as compared with the treatment with $100 \%$ substitution. This increased would reach up to $22.6 \%$ using a passage rate of $0.05 \mathrm{~h}^{-1}$ (Table 7).

At the end of the incubation trial, NDF degradation responded quadratically, reaching its highest value at around $42.03 \%$ of substitution of NPN for true protein, based on the derivation of the equation (Fig. 2).

\section{Discussion}

The mean rumen ammonia values at $48 \mathrm{~h}$ of incubation (Table 2) in all treatments were higher than the minimum threshold of 4 to $5 \mathrm{mg} \mathrm{dL}^{-1}$ recommended by Satter and Slyter (1974) for degradation of NDF. The present values are also above the $10 \mathrm{mg} \mathrm{dL}^{-1}$ recommended by Soest (1994) for adequate microbial growth on carbohydrates and for optimum NDF degradation.

In the treatment with $100 \%$ substitution, the $\mathrm{N}-\mathrm{NH}_{3}$ concentration of $10 \mathrm{mg} \mathrm{dL}$ was attained at $24 \mathrm{~h}$ of incubation, whereas the other treatments, containing different proportions of casein and urea, reached this minimum concentration at $9 \mathrm{~h}$ of incubation (Fig. 1a). This had an impact on microbial growth, which was lower throughout the incubation period when nitrogen originated only from the true protein (Fig. 1b). A possible explanation for this finding is the fact that urea is more efficient in providing larger levels of ammonia nitrogen than casein when equal levels of protein are supplemented (Zorzi et al. 2009).

According to Leng (1990), 10 to $20 \mathrm{mg} \mathrm{N}-\mathrm{NH}_{3} \mathrm{dL}^{-1}$ are necessary for maximising rumen degradation of lowquality tropical grasses. This $\mathrm{N}-\mathrm{NH}_{3}$ concentration improves the efficiency of microbial synthesis by 15 to $28 \%$, regardless of the nitrogen source (Kanjanapruthipong and Leng 1998). In the present study, the longest time to reach the minimum $\mathrm{N}^{-\mathrm{NH}_{3}}$ value necessary for maximum NDF degradation was observed for the treatment with $100 \%$ substitution of NPN.

Diets formulated with different nitrogen sources that meet the rumen-degradable protein requirements can improve the uptake of nutrients to the most diverse groups of rumen microorganisms, increasing the efficiency of microbial protein synthesis. Furthermore, as shown in Fig. 1 , these diets allow a more synchronous release of nitrogen sources for microbial growth. Bowen et al. (2016) found no differences regarding the source used (urea or casein) on the efficiency of microbial protein synthesis using a low-quality tropical grass. In this same study, there was a difference in the amount of casein used to maximise the efficiency of microbial synthesis, which was only increased when a greater uptake of digestible organic matter was provided. This improvement was associated with a four-fold increase in the concentration of $\mathrm{N}^{-\mathrm{NH}_{3}}$, in the rumen fluid, resulting from greater degradation of the dietary protein. The presence of true protein is important in the synthesis of amino acids by cellulolytic bacteria such as branched-chain volatile fatty acids (Bowen et al. 2016); however, they also use ammonia as a nitrogen source to synthesise microbial 
Table 7: Estimates of effectively degraded fraction of potentially degradable neutral detergent fibre (\% of pdNDF) according to the substitution of non-protein nitrogen for true protein

\begin{tabular}{llcc}
\hline Treatment & \multicolumn{3}{c}{ Rumen passage rate $\left(\mathrm{h}^{-1}\right)^{1}$} \\
\cline { 2 - 4 } & 0.020 & 0.035 & 0.050 \\
\hline $0 \%$ & 35.88 & 31.36 & 27.65 \\
$25 \%$ & 34.27 & 30.26 & 26.91 \\
$50 \%$ & 32.85 & 29.22 & 26.17 \\
$75 \%$ & 33.73 & 29.24 & 25.59 \\
$100 \%$ & 30.28 & 25.99 & 22.55 \\
\hline${ }^{1}$ Assuming ruminal displacement flow kinetics of solids with gamma-1 distribution.
\end{tabular}
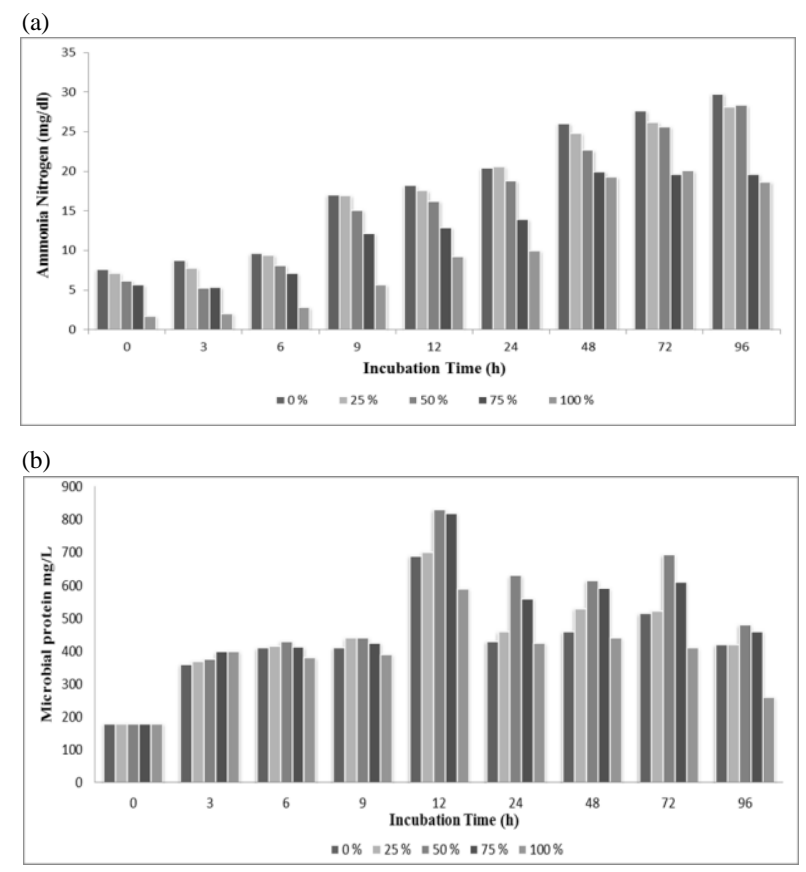

Fig. 1: Effect of substitution of non-protein nitrogen (NPN) for true protein (TP) on the concentrations of ammonia (a) and microbial protein (b) over $96 \mathrm{~h}$ of in vitro incubation

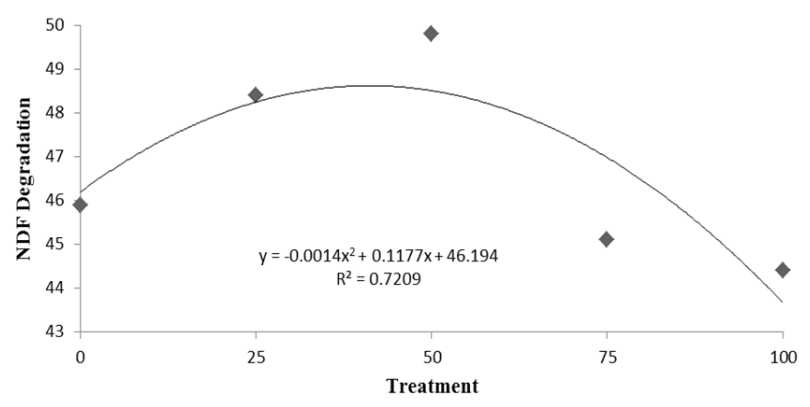

Fig. 2: Degradation of NDF (\%) according to the substitution of the nitrogenous-compound source

protein, which is likely explained by the greater microbial protein synthesis seen in the $50 \%$ substitution treatment.

All $\mathrm{pH}$ values found remained above the minimum limits for fibrolytic activity (Ørskov 1986). For Martins et al. (2006), $\mathrm{pH}$ values higher than 6.0 favour the maintenance of an adequate rumen medium for cellulolytic bacteria to adhere to the particles (Cysneiros et al. 2013). Rasmussen et al. (1989) did not observe effects of $\mathrm{pH}$ changes between 6.0 and 8.0 on bacterial adherence, indicating that $\mathrm{pH}$ values slightly above 7.0 may favour NDF degradability.

According to Júnior et al. (2004), decreased ammonia production is expected to increase propionate production and a consequent decrease in the acetate/propionate ratio in the rumen. However, no such effect was observed in the present study. Despite the different $\mathrm{N}-\mathrm{NH}_{3}$ concentrations at the different urea and casein ratios, there was no change in $\mathrm{pH}$ values, which is a key factor to the proliferation of cellulolytic microorganisms (Russell and Wilsom 1996), the main producers of acetate. As a result, the fermentation of the substrate used becomes uniform regardless of the NPN and TP ratios.

The molar proportions of acetate and propionate were $68.8 \%$ and $28.2 \%$, respectively, which are within the normal ranges of 54 to $74 \%$ (acetate) and 16 to $27 \%$ (propionate) proposed by Silva and Leão (1979) and by Filho and Pina (2011). Although the present study was conducted in a closed and restricted system (in vitro) and despite the fact that the rumen is a dynamic environment, with passage of solids and liquids and entry of saliva and feed, our results corroborate in vivo studies (Heldt et al. 1999; Laguna et al. 2013; Gonçalves et al. 2015).

Butyrate concentrations increased because the bacteria that use the butyrate pathway for the reoxidation of $\mathrm{NADH}_{2}$ usually have only this pathway for VFA production, having no enzymes that are able to utilise other mechanisms to generate another end product (Moss et al. 2000). In this way, butyrate-producing cellulolytic bacteria show affinity in the use of the products from the fermentation of amino acids and small peptides derived from the degradation of true protein; e.g. branched-chain VFA.

Our results regarding total VFA concentrations and individual quantities of each VFA contrast with those reported by Xin et al. (2010), who did not observe differences in the concentrations of total VFA produced from diets with different protein sources (soy protein isolate, livestock urea, and encapsulated urea). However, these treatments significantly changed the molar percentages of individual VFA, with the urea-based diets resulting in larger acetate and smaller propionate proportions in comparison with the soybean meal-based diet, leading to an increase in the acetate/propionate ratio.

The $\mathrm{N}-\mathrm{NH}_{3}$ levels and the supply of a true-protein source have a direct influence on the fermentation of the substrates present in the rumen, since these compounds participate in the synthesis of nitrogenous bases and serve as donors of carbon backbones, respectively. This explains the increase in total VFA when these compounds were combined at the substitution level of 50\%.

The highest concentration of total VFA was observed in the treatment with $50 \%$ substitution. This can be 
explained by the fact that the supply of a true-protein source, such as casein, is important for fermentation and microbial growth, since amino acids provide carbon backbones when degraded. Within addition to ammonia, which is generated by the hydrolysis of urea, carbon backbones are used for the synthesis of microbial protein (Ribeiro et al. 2014). Detmann et al. (2011) demonstrated $24 \%$ and $96 \%$ increases in fibre degradation with the supply of $1 / 3$ and $1 / 2 \mathrm{TP}$ in comparison with treatments with urea addition and without addition of any nitrogenous compounds, respectively.

The discrete lag time observed in our study can be attributed to some factors. One of them is the ammonia concentration in the rumen fluid. According to Detmann et al. (2009), inefficiency in the concentration of ammonia in the rumen fluid may lead to a microbial deficiency in the synthesis of compounds necessary for microbial adherence on the fibre or production of enzymes to initiate the fibre degradation. Other important factors that possibly explain the higher degradation rate of pdNDF and lower discrete lag time in combined-supplementation situations are the constant maintenance of high ammonia values in the medium, favouring cellulose- and hemicellulose-degrading bacteria, and providing the requirements of the many species of the rumen environment. In general, fibrous carbohydrate-fermenting cellulolytic and hemicellulolytic bacteria use ammonia nitrogen as the main source of nitrogen for microbial growth. However, non-fibrous carbohydrate-fermenting bacteria use amino acids as a nitrogen source. Because the incubation medium in the present study was rich in fibrous carbohydrates (Table 1), the treatments providing larger amounts of TP compromised effective fibre degradation.

According to Kozloski (2011), amino acids are catabolised and converted to branched-chain fatty acids (isobutyrate, isovalerate) by bacteria with high deaminating activity. These are essential substrates for the growth of fibrous carbohydrate-degrading bacteria, increasing the potential of pdNDF fermentation and generating a higher concentration of VFA, which are responsible for $70-80 \%$ of the energy available to the ruminant.

Franco et al. (2004) stated that increasing concentrations of ammonia nitrogen favour the proliferation of fibrous carbohydrate-degrading bacteria, increasing the pdNDF degradation rate. Ammonia is of critical importance for the degradation of carbohydrates, since it is used by microorganisms that degrade the cellulose and hemicellulose from the plant cell wall for cellular growth and multiplication Russell et al. (1992). However, besides ammonia, those microorganisms also need branched-chain fatty acids (isovalerate, isobutyrate) that originate from the degradation of branched-chain proteins, such as leucine, isoleucine, and valine, for the synthesis of microbial proteins (Haraguchi et al. 2006). Therefore, it can be affirmed that the interaction between urea and casein provided the best conditions for NDF degradation, since the treatment containing equal amounts of the two nitrogenous compounds had the best degradation rates.

Sampaio et al. (2009) mentioned that the requirement of nitrogenous compounds by rumen microorganisms is approximately $7 \% \mathrm{CP}$, and that values lower than this compromise microbial growth. The basal $\mathrm{CP}$ content of $4.98 \%$ found in the forage used in the present experiment is lower than the recommended above-mentioned value.

Similar results were found by Zorzi et al. (2009), who observed a deleterious effect of casein inclusion, where a $0.5 \mathrm{mg} \mathrm{mL} \mathrm{m}^{-1}$ increment resulted in a $1.1 \%$ higher rate of pdNDF degradation. However, the use of casein at levels higher than 1.0 and $2.0 \mathrm{mg} \mathrm{mL}^{-1}$ had an inhibitory effect on the estimates of this parameter compared with the treatment containing forage only, reducing this variable by 6.4 and $9.1 \%$. The same authors found that supplementation with urea only, irrespective of the level, increased the degradation rate of pdNDF.

According to Detmann et al. (2011), the maximum values found for potentially degradable NDF and microbial efficiency were achieved when the non-protein nitrogen and true protein ratios were $2 / 3$ and $1 / 3$. According to these authors, protein supplement balancing optimises the degradation of NDF from low-quality forages for cattle. Another parameter that can be associated with improved utilisation of NDF in relation to the use of NPN and TP is discrete lag time (L). Detmann et al. (2011) described discrete lag time as the estimate (by approximation) of the time required for the events preceding the NDF degradation activities, which involve hydration, fixation to the substrate, and enzyme synthesis.

Higher efficiency in microbial protein production has considerable importance in ruminant nutrition. Fernandes et al. (2015) mentioned that microbial protein is considered to be of high biological value, with $62.5 \%$ crude protein, $60 \%$ of which is true and available and contains the complete amino acid profile for ruminants, in addition to accounting for 50 to $80 \%$ of the protein absorbable in the intestine (Bach et al. 2005). Given these facts, the data demonstrate the importance of adequate supplementation with NPN and true-protein sources for rumen microorganisms, since they are critically important for animal's biological response. In addition to helping degrade the feed, the lager number of microorganisms present which serve as a source of proteins to the host animal.

Because it is a parameter derived directly from the degradation rate of pdNDF, the effectively degraded fraction of pdNDF should respond similarly to the other studied parameters. However, no such trend was observed in the present study. Although the potentially degradable fraction of NDF (U) is dependent of the substrate (forage) (Detmann et al. 2011), different values are assigned to each treatment according to the type and utilisation of nitrogenous supplementation, aiming to increase the potentially degradable fraction and consequently reduce the undegradable fraction. This occurs because supplementation 
with different types of nitrogenous compounds modifies the rumen medium, which may or may not promote an environment that allows for better degradation of NDF. A difference is thus observed in the effectively degraded fraction of pdNDF regarding degradation rates: supplementation with non-protein nitrogen and true protein benefits the digestion of the fibre from buffel grass both in the extent of its degradation by the rumen microorganisms and in the synthesis of microbial protein (Costa et al. 2008).

\section{Conclusion}

The use of $50 \%$ non-protein nitrogen and $50 \%$ true protein as the nitrogen source for rumen microorganisms optimises the degradation of neutral detergent fibre from low-quality buffel grass and microbial growth in vitro. Further in vivo studies are warranted to test this hypothesis.

\section{Author Contributions}

JSO and CJBO designed the project. JASN and JSO wrote the manuscript. JSO, CJBO, CASS, EMS and ECBC designed the methodology and collected the data. CASS, RMAP and EMS conceptualized the idea for this work and critically revised the manuscript. CJBO, JSO and AFP approved the final version of the manuscript.

\section{References}

AOAC (2012). Official Methods of Analysis, $19^{\text {th }}$ edn. AOAC International, Gaithersburg, Maryland, USA

Arruda AMV, MCA Neto, PCF Linhares, MRGF Costa, ES Pereira (2010). Digestibilidade in vitro da jitirana com inóculo cecal de avestruzes. Rev Bras Saúde Prod Anim 11:474-483

Bach A, S Calsamiglia, MD Stern (2005). Nitrogen metabolism in the rumen. J Dairy Sci 88:9-21

Beuvink JMW, J Kogut (1993). Modeling gas production kinetics of grass silages incubated in ruminal fluid. J Anim Sci 71:1041-1046

Bowen MK, DP Poppi, SR McLennan (2016). Effect of quantity and source of rumen nitrogen on the efficiency of microbial protein synthesis in steers consuming tropical forage. Anim Prod Sci 58:811-817

Bradford MM (1976). A rapid and sensitive method for the quantitation of microgram quantities of protein utilizing the principle of protein-dye binding. Anal Biochem 72:248-254

Chaney AL, EP Marbach (1962). Modified reagents for determination of urea and ammonia. Clin Chem 8:130-132

Costa VAC, E Detmann, SCV Filho, MF Paulino, LT Henriques, HC Mantovani (2008). Degradação in vitro da fibra em detergente neutro de forragem tropical de baixa qualidade em função de suplementação com proteína e/ou carboidratos. Rev Bras Zootec 37:494-503

Cysneiros CSS, RN Ferreira, MA Oliveira, AO Favoretto, E Arnhold, CJ Ulhoa (2013). Produção, caracterização e avaliação de enzimas fibrolíticas na digestibilidade da forragem de milho. Ciênc Anim Bras 14:426-435

Detmann E, AC Queiroz, K Zorzi, HC Mantovani, GFV Bayão, MPC Gomes (2011). Degradação in vitro da fibra em detergente neutro de forragem tropical de baixa qualidade em função da suplementação com proteína verdadeira e/ou nitrogênio não proteico. Rev Bras Zootec 40:1272-1279

Detmann E, MF Paulino, HC Mantovani, SCV Filho, CB Sampaio, MA Souza, I Lazzarini, KSC Detmann (2009). Parameterization of ruminal fibre degradation in low-quality tropical forage using Michaelis-Menten kinetics. Livest Sci 126:136-146
Ellis WC, JH Matis, TM Hill, MR Murphy (1994). Methodology for estimating digestion and passage kinetics of forages. In: Forage Quality, Evaluation, and Utilization, pp:682-756. Collins M, DR Martens, LE Moser (Eds.). American Society of Agronomy, Madison, Wisconsin, USA

Fernandes RM, CM Almeida, BC Carvalho, JÁA Neto, VAC Mota, FD Resende, GR Siqueira (2015). Effect of supplementation of beef cattle with different protein levels and degradation rates during transition from the dry to rainy season. Trop Anim Health Product 48:95-101

Filho SCV, DS Pina (2011). Fermentação ruminal. In: Nutrição de Ruminantes, pp:161-189. Berchielli TT, AV Pires, SG Oliveira, SG Funep (Eds.). Jaboticabal, Brazil

Franco AVM, GL Franco, P Andrade (2004). Parâmetros ruminais e desaparecimento da MS, PB e FDN da forragem em bovinos suplementados em pastagem na estação seca. Rev Bras Zootec 33:1316-1324

Gonçalves AP, CFM Nascimento, FA Ferreira, RC Gomes, MQ Manella, CT Marino, JJAA Demarchi, PHM Rodrigues (2015). Slow-release urea in supplement fed to beef steers. Braz Arch Biol Technol 58:22-30

Haraguchi FK, WC Abreu, H Paula (2006). Proteínas do soro do leite: Composição, propriedades nutricionais, aplicações no esporte e benefícios para a saúde humana. Rev Nutr 19:479-488

Heldt JS, RC Cochran, CP Mathis, BC Woods, KC Olson, EC Titgemeyer, TG Nagaraja, ES Vanzant, DE Johnson (1999). Effects of level and source of carbohydrate and level of degradable intake protein on intake and digestion of low-quality tallgrass-prairie hay by beef steers. J Anim Sci 77:2846-2854

Júnior DS, AC Queiroz, RP Lana, CG Pacheco, EC Eifert, PMM Nunes (2004). Ação da própolis sobre a desaminação de aminoácidos e a fermentação ruminal. Rev Bras Zootec 33:1086-1092

Kanjanapruthipong J, RA Leng (1998). A comparison of ammonia and preformed protein as a source of nitrogen for microbial growth in the rumen of sheep given oaten chaff. Asian-Aust J Anim Sci 11:351-362

Kozloski GV (2011). Bioquímica dos Ruminantes, $3^{\text {th }}$ edn. Editora da UFSM, Santa Maria, RS, Brazil

Laguna JG, AN Rodrigues, HM Saturnino, JRM Ruas, SG Coelho, RB Rei (2013). Alimentação de vacas F1 Holandês x Zebu com suplementos nitrogenadose monensina sódica: Avaliação do consumo, parâmetros ruminais e produção de leite. Arq Bras Med Vet 65:841-846

Leng RA (1990). Factors affecting the utilization of poor-quality forages by ruminants particularly under tropical conditions. Nutr Res Rev 3:277-303

Licitra G, TM Hernandez, PJV Soest (1996). Standardization of procedures for nitrogen fractionation of ruminant feeds. Anim Feed Sci Technol $57: 347-358$

Mallmann GM, HO Patino, ALF Silveira, FS Medeiros, M Knorr (2006). Consumo e digestibilidade de feno de baixa qualidade suplementado com nitrogênio não protéico em bovinos. Pesq Agropec Bras 41:331-337

Martins AS, PF Vieira, TT Berchielli, IN Prado, RC Canesin, MC Setti (2006). Taxa de passagem e parâmetros ruminais em bovinos suplementados com enzimas fibrolíticas. Rev Bras Zootec 35:1186-1193

Milgen JV, LL Murphy, LL Berger (1991). A compartmental model to analyze ruminal digestion. J Dairy Sci 74:2515-2529

Moss AR, JP Jouany, J Newbold (2000). Methane production by ruminants: Its contribution to global warming. Ann Zootech 49:231-253

Ørskov ER (1986). Starch digestion and utilization in ruminants. Anim Sci J 63:1624-1633

Ørskov ER, I McDonald (1979). The estimation of protein degradability in the rumen from incubation measurements weighted according to rate of passage. J Agric Sci 92:499-503

Pirt SJ (1965). The maintenance energy of bacteria in growing cultures. Proc Roy Soc B 163:224-231

Rasmussen MA, BA White, RB Hespell (1989). Improved assay for quantitating adherence of ruminal bacteria to cellulose. Appl Environ Microbiol 55:2089-2091

Ribeiro PR, GLM Junior, SP Silva (2014). Aspectos nutricionais da utilização da proteína pelos ruminantes. Vet News 20:1-14 
Russell JB, DB Wilson (1996). Why are ruminal cellulolytic bacteria unable to digest cellulose at low pH? J Dairy Sci 79:1503-1509

Russell JB, JD O'Connor, DG Fox, PJV Soest, CJ Sniffen (1992). A net carbohydrate and protein system for evaluating cattle diets: I. Ruminal fermentation. J Anim Sci 70:3551-3561

Russell JB, SA Martin (1984). Effects of various methane inhibitors on the fermentation of amino acids by mixed rumen microorganisms in vitro. Anim Sci J 59:1329-1338

Sampaio CB, E Detmann, I LazzarinI, MA Souza, MF Paulino, SCV Filho (2009). Rumen dynamics of neutral detergente fiber in cattle lowquality tropical forage and supplemented with nitrogenous compounds. Rev Bras Zootec 38:560-569

Santos GRA, A Guim, MVF Santos, MA Ferreira, MA Lira, JCB Dubeux Júnior, MJ Silva (2005). Caracterização do pasto de Capim-buffel diferido e da dieta de bovinos, durante o período seco no sertão de Pernambuco. Rev Bras Zootec 34:454-463

Satter LD, LL Slyter (1974). Effect of ammonia concentration on rumen microbial production in vitro. Brit J Nutr 32:199-208

Silva JFC, MI Leao (1979). Fundamentos de nutrição dos ruminantes. Livroceres, Piracicaba, Brazil
Sniffen CJ, JD O’Connor, PJV Soest, DG Fox, JB Russell (1992). A net carbohydrate and protein system for evaluating cattle diets: Carbohydrate and protein availability. J Anim Sci 70:3562-3577

Soest PJV (1994). Nutritional Ecology of the Ruminant, $2^{\text {nd }}$ Edition. Cornell University Press, Ithaca

Soest PJV (1967). Development of a comprehensive system of feeds analysis and its applications to forages. J Anim Sci 26:119-128

Vieira RAM, JC Pereira, PAM Malafaia, AC Queiroz (1997). The influence of elephantgrass (Pennisetum purpurem Schum. Mineiro variety) growth on the nutrient kinetics in the rumem. Anim Feed Sci Technol 66:197-210

Xin HS, DM Schaefer, QP Liu, DE Axe, QX Meng (2010). Effects of polyurethane coated urea supplement on in vitro ruminal fermentation, ammonia release dynamics and lactating performance of Holstein dairy cows fed a steam-flaked corn-based diet. AsianAust J Anim Sci 23:491-500

Zorzi K, E Detmann, AC Queiroz, MF Paulino, HC Mantovani, GF Bayão (2009). In vitro degradation of neutral detergent fiber of high-quality tropical forage according to supplementation with different nitrogenous compounds. Rev Bras Zootec 8:964-971 